Editor-in-Chief Adel Barbara

\title{
International Journal of
Keratoconus and \\ International Journal of
Keratoconus and Ectatic Corneal Ectatic Corneal
Diseases
}

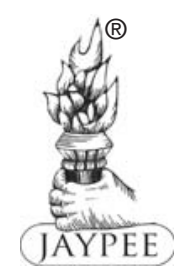

www.jaypeebrothers.com

www.jaypeejournals.com 


\section{International Journal of Keratoconus and Ectatic Corneal Diseases}

\section{Aims and Scope}

The International Journal of Keratoconus and Ectatic Corneal Diseases is a peer-reviewed journal covering keratoconus and other ectatic corneal diseases, including pellucid marginal degeneration, Terrien's marginal degeneration, keratoglobus and iatrogenic keratoconus, such as post-lasik ectasia. Studies dealing with epidemiology, genetics, pathology and corneal biomechanics are welcomed.

The journal covers new diagnostic tools that aid in the diagnosis of keratoconus and ectatic corneal diseases including their role in refractive surgery.

The journal deals with new treatment modalities, such as collagen corneal cross-linking, intrastromal corneal rings, anterior lamellar keratoplasty, deep anterior lamellar keratoplasty and the applications of femtosecond lasers in penetrating kertoplasty and corneal surgery. In addition, the journal covers the use of excimer laser in corneal surgery. Special interest is drawn to contact lenses and their use in keratoconus and ectatic corneal diseases.

The above-mentioned topics have a crucial role in the clinical practice and day-to-day management.

The journal aims to publish articles arising out of original research, specialized topics, review articles, editorials and descriptions of new diagnostic and therapeutic techniques and technologies. In addition, the journal includes pictorial reviews, letters to the editor, book reviews and notices of meetings and courses. In this way the journal hopes to provide a forum for the stimulation of new developments, clinical practices and research in its field.

\section{Ethical Considerations}

Manuscripts submitted for publication must comply with the following ethical considerations:

\section{Informed Consent}

Informed consent of the patients must be taken before they are considered for participation in the study. Patient identifying information, such as names, initials, hospital numbers or photographs should not be included in the written descriptions. Patient consent should be obtained in written and archived with the authors.

\section{Protection of Human Subjects and}

\section{Animals in Research}

When conducting experiments on human subjects, appropriate approval must have been obtained by the relevant ethics committees. All the procedures must be performed in accordance with the ethical standards of the responsible ethics committee both (institutional and national) on human experimentation and the Helsink Declaration of 1964 (as revised in 2008). When reporting experiments on animals, authors must follow the institutional and national guidelines for the care and use of laboratory animals.

\section{Copyright}

Following guidelines must be followed before submission of the manuscript:

The articles must represent original research material, should not have been published before and should not be under consideration of publication elsewhere. This, however, does not include previous publication in form of an abstract or as part of published literature (review or thesis). It is the duty of the author to obtain the necessary permissions for extensive quotations, tables, illustrations or any other copyrighted material they are using in the paper before a paper can be considered for publication. Copyright of the article gets transferred to Jaypee Brothers, once the article has been accepted for publication. The author would be asked to sign the "Copyright Transfer Form" before his/her article is considered for publication. Once the Copyright Transfer statement has been signed by the corresponding author, no change in authorship or in the order of the authors listed on the article would be accepted by Jaypee Brothers. Also by signing the above mentioned form, the author reassigns the rights of copublishing, or translation if considered necessary in future to the publisher. In the advent of occurrence of any dispute, the matter would be resolved within the jurisdiction of New Delhi court.

While all care has been taken to provide accurate and correct information in accordance with the date of publication, neither the authors, editors not the publisher takes any legal responsibility for any unintentional omission or error. The publisher makes no expressed or implied warranty with respect to the information contained herein. The published material cannot be photocopied for the following purposes: General distribution, promotion, new works or resale. If this is required, specific written permission requires to be obtained from the publisher. Exclusive rights to reproduce and distribute the articles in this journal have been protected by copyright. This also covers the rights to reproduce or distribute the article as well as the translation rights. No material published in this journal can be reproduced in digital format or stored in form of electronic databases, video disks, etc.

Both the conflict of interests and financial disclosure needs to be handled well while conducting the research study. Disclosure of such relationships is also important in connection with all articles submitted for publication. Both of these have also been included in the Copyright Transfer Form. Authors should give due acknowledgement to the individuals who provide writing or other assistance while conducting the research study and also disclose the funding source for the research study.

\section{Subscription Information}

ISSN 2277-3800 elSSN 2277-4203

\section{- Subscription rates}

For information on subscription rates and the other journal-related enquiries please contact:

journals@jaypeebrothers.com

\section{- Orders}

Journals Department

Jaypee Brothers Medical Publishers (P) Ltd

4838/24, Ansari Road, Daryaganj

New Delhi 110 002, India

Phone: +91-11-4357 4357

Fax: +91-11-4357 4314

e-mail: subscriptions@jaypeejournals.com

Back volume. Prices are available on request.

\section{Electronic Media}

An electronic edition of this journal is available at www.jaypeejournals.com

Manuscripts can be submitted online at www.ijkecd.com

\section{Advertisement}

For advertisement queries please contact: Journals Department

Jaypee Brothers Medical Publishers

e-mail: advertisements@ @aypeejournals.com

For any queries regarding online submission, please e-mail us at: help-desk@jaypeejournals.com

For editorial queries, please contact:

chetna.malhotra@jaypeebrothers.com

The Journal is printed on acid free paper.

\section{Copyright}

(C) Jaypee Brothers Medical Publishers (P) Ltd.

www.jaypeebrothers.com

www.jaypeejournals.com 


\author{
Editor-in-Chief \\ Adel Barbara (Israel) \\ Co-Editor \\ Ambrosio Renato Jr (Brazil)
}

\section{Publishing Center \\ Publisher \\ Jitendar P Vij \\ Senior Manager \\ Chetna Vohra \\ Managing Editor \\ Ekta Aggarwal \\ Editorial Associate \\ Pankaj K Singh \\ Creative Designer}

Radhe Shyam Singh

\section{Editorial Office}

Journals Department

Jaypee Brothers Medical Publishers $(P)$ Ltd.

4838/24, Ansari Road, Daryaganj

New Delhi-110 002, India

Phone: +91-11-43574357

Fax: $+91-11-43574314$

e-mail: journals@ jaypeebrothers.com

\section{Production Office}

Jaypee Brothers Medical Publishers $(P)$ Ltd.

4838/24, Ansari Road, Daryaganj

New Delhi-110 002, India

Phone: +91-11-43574357

Fax: $+91-11-43574314$

e-mail: journals@jaypeebrothers.com

\section{Advertisements}

Rakesh Sheoran

Phone: +91-9971020680

e-mail: advertisements@ jaypeejournals.com

rakesh.sheoran@jaypeebrothers.com

\section{Subscriptions/Reprints}

Abhinav Kumar

Phone: +91-9810279794

e-mail: subscriptions@ @aypeejournals.com

abhinav.kumar@jaypeebrothers.com

\section{Website Manager}

Rohit Gorawara

Phone: +91-9871855331

e-mail: contact@ @aypeejournals.com

rohit.gorawara@ jaypeebrothers.com

\section{Editorial Board Members}

$$
\text { Alió Jorge (Spain) }
$$

Belin Michael (USA)

Busin Massimo (Italy)

Colin Joseph (France)

David Smadja (France)

David T Touboul (France)

Daxer Albert (Austria)

Daya Sharma (Australia)

Daya Sheraz (UK)

Ferrara Paulo (Brazil)

Gatinel Damien (France)

Hafezi Farhad (Switzerland)

Jörg H Krumeich (Germany)

Kılıç Aylin (Turkey)

Krueger Ronald (USA)

Kymionis George (Greece)

Laroche Laurent (France)

Malecaze Fracois (France)

Marguerite McDonald (USA)

Mauger Thomas (USA)

Mortensen Jes (Sweden)

O'Brart David (UK)

Oyarzun Mario (Chile)

Palikaris loannis (Greece)

Paolo Vinceguerra (Italy)

Rabinowitz Yaron (USA)

Raiskup Frederic (Germany)

Reinstein Dan (UK)

Roberts Cynthia (USA)

Rootman S David (Canada)

Saad Alain (France)

Salgado-Borges, José (Portugal)

Seiler Theo (Switzerland)

Siganos Charalambos (Greece)

Spörl Eberhard (Germany)

Stephen Klyce (USA)

Tassignon Marie-Jose (Belgium)

Vardhaman Kankaria (India)

Vryghem C Jérôme (Belgium)

William Traftler (USA)

Zadok David (Israel) 


\section{International Journal of \\ Keratoconus and Ectatic \\ Corneal Diseases}

January-April 2013 Volume 2 Number 1

\section{Contents}

\section{Original Articles}

- A Prospective C linical E valuation of a New Scleral C ontact Lens for Patients with Distorted C orneas

Philip Fine, Ariela Gordon-Shaag, Esther Leibowitz, Ayelet Chen Lahav,

Steven J ackson, Renana Halperin, Liat Gantz

- The Influence of C orneal V olume in Surgical Planning: Insights for a New Parameter for the Ferrara Ring Nomogram

Leonardo Torquetti, G uilherme F errara, Wagner Gomes Dias, Paulo F errara

- O utcomes of Corneal C ollagen C ross-linking for K eratoconus the E ffect of Cone Location

Vinay Agrawal

\section{Review Articles}

- Deep Anterior L amellar K eratoplasty for E ctatic Disease.

20-27

Allan Luz, Luciene Babosa, B runo Machado F ontes, Isaac Ramos,

Paulo Schor, Renato Ambrósio J $r$

- The R ole of Scleral Lens in E ctatic C orneas.

Ilya Ortenberg, Shmuel Behrman

- History of the Development of the Treatment of Keratoconus

Lamis Abdelaziz, Ramez Barbara

\section{CAse Series}

- Long-term Follow-up of Ferrara R ings Segments for the Treatment of K eratoconus

Adel Barbara, Ramez Barbara

\section{CASE Reports}

- Explantation and R otation of Intracorneal Ring Segments with the Support of Femtosecond Laser: An Asymmetrical Version 40-42

E Levinger, S Levinger, A Hirsh

- Spontaneous C orneal R upture O ne W eek after Intrastromal Ring Segment Surgery 43-46 Agostino Salvatore Vaiano, Giacomo De Benedetti, Rosanna Perno, Gaudioso del M onte, Cristiana Valente, Guido Caramello 


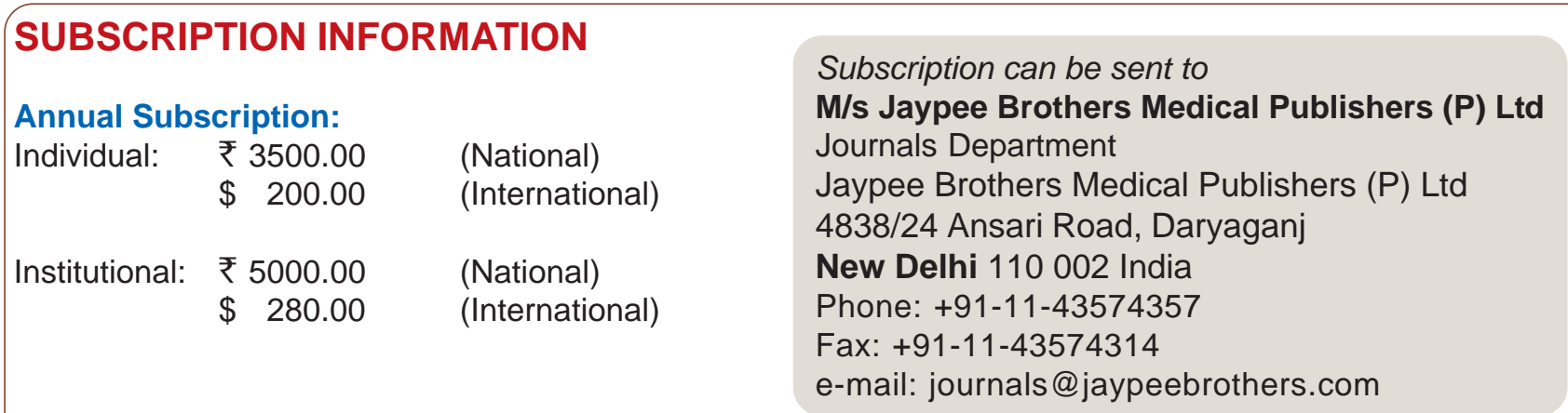

This journal is published thrice in a year, i.e. J anuary, May and September. Dollar rates apply to subscribers in all the countries except India where INR price is applicable. All subscriptions are payable in advance and all the rates include postage. J ournals are sent by air to all the countries except Indian subcontinent. Subscriptions are on an annual basis, i.e. from J anuary to December. Payment will be made by dollar cheque, credit card or directly through our bank account at the following address:
1. Our Banker's Name:
Canara Bank, Netaji Subhash Marg
2. Telephone No:
Darya Ganj, New Delhi 110002
3. Fax No:
011-23273015, 011-23273849
4. Telex No:
011-23255606
3166291
5. Our Current A/C No:
3828
6. Amount to be Transferred
JAYPEE BROTHERS MEDICAL
in the Name of:
7. Swift Code No:
PUBLISHERS (P) LTD., NEW DELHI
CNRB IN BB DFM
For further queries, please do not hesitate to contact at subscriptions@ jaypeejournals.com

\section{ADVERTISEME NT RATES \\ (For the Print Issues) \\ Page \\ Back cover-color \\ Inside front cover-color \\ Inside back cover-color \\ Inside full page-color \\ Special position: Price on request}

Technical Details

Paper size

Print size

Digital file format

Printed on art paper using offset printing.

$8.25 \times 11.75$ inches

$7 \times 10$ inches

EPS on CD (at 300 dpi resolution)

\section{Schedule}

Issues are published in the months of J anuary, May and September.

Advertisement material along with purchase order and payment should reach us at least four weeks prior to the scheduled print date.

\section{Payment Details}

- Payment should favour "J aypee B rothers Medical Publishers (P) Ltd." and should be payable at New Delhi, India.

- Payment to be done at the time of submitting the advertisement material/booking the advertisement. Please send your advertisement request, payment and advertisement material to the address given above. Editorial board reserves the right to accept or decline the advertisement.

For further queries, please contact advertisements@ jaypeejournals.com 